\title{
Chemical of Soils With Histic Horizon of Lakes and Riparian of the Savanna, Northern Amazonia, Brazil
}

\author{
Ednalva Dantas R. S. Duarte, ${ }^{1,2}$, Valdinar F. Melo ${ }^{3}$, Etelvino H. Novotny ${ }^{4}$, Sandra Cátia P. Uchôa ${ }^{3}$, \\ Hugo Leonardo S. Farias ${ }^{5}$, Gustavo Vieira Veloso ${ }^{6}$, Ronilson José P. Amorim ${ }^{7}$, \\ Taiane Maíza de Lira Carneiro Matias ${ }^{7} \&$ João Victor de Paiva Cabral ${ }^{7}$ \\ ${ }^{1}$ Department of Chemical, Federal University of Roraima, Boa Vista, Roraima, Brazil \\ ${ }^{2}$ Graduate Program of the Amazonian Biotechnology, Biodiversity and Conservation (Bionorte Network), \\ Federal University of Roraima, Boa Vista, Roraima, Brazil \\ ${ }^{3}$ Department of Soils and Agricultural Engineering, Federal University of Roraima, Boa Vista, Roraima, Brazil \\ ${ }^{4}$ Embrapa Solo, Rio de Janeiro, RJ, Brazil \\ ${ }^{5}$ Graduate Program in Natural Resources, Federal University of Roraima, Boa Vista, Roraima, Brazil \\ ${ }^{6}$ Graduate Program in Soil Scicnece, Federal University of Vicosa, Viçosa, Minas Gerais, Brazil \\ ${ }^{7}$ Undergraduate of Agronomy, Federal University of Roraima, Boa Vista, Roraima, Brazil \\ Correspondence: Ednalva Dantas R. S. Duarte, Department of Chemical, Federal University of Roraima, Boa \\ Vista, Roraima, Brazil, Av. Cap. Enê Garcez, 2413, Boa Vista, Roraima, Brazil. Tel: 55-095-981-166-904. E-mail: \\ ednalva.duarte@ufrr.br
}

Received: September 5, 2018

Accepted: October 13, 2018

Online Published: December 15, 2018

doi:10.5539/jas.v11n1p159

URL: https://doi.org/10.5539/jas.v11n1p159

\begin{abstract}
The savanna of the northern Amazon of Brazil is an ecosystem that presents lakes and riparian of buriti (Mauritia flexuosa L.) in its landscape. Although these ecosystems are protected by law, they are subject to changes by anthropization in their surrounding areas. The soils of lakes and on the banks of the buriti riparian of the savanna of Boa Vista, Northern Amazonia, are hydromorphic and, although they are important ecosystems for the environmental sustainability, they are little studied. Thus, the purpose of this work was to characterize the chemical composition of these soils and relate the results to the type of anthropization. Samples were collected at the margins of five riparian and three lakes in the $0.0-0.1,0.1-0.2,0.2-0.3,0.3-0.4$, and $0.4-0.5 \mathrm{~m}$ depth layers. Soil samples, in each environment, were taken from three points equidistant at $100 \mathrm{~m}$. For soil characterization, $\mathrm{pH}$ in water, $\mathrm{H}+\mathrm{Al}, \mathrm{Al}^{3+}, \mathrm{P}^{+}, \mathrm{Mg}^{2+}, \mathrm{Ca}^{2+}$, and total organic $\mathrm{C}$ (TOC) were determined. The soils of lakes and buriti riparian are of high acidity, low natural fertility, and high toxicity by Al. Buriti riparian presented the highest levels of TOC but were also the environments most susceptible to the effects of anthropization, in which Bom Intento presented values of available $\mathrm{P}$ from medium to high by the interference of agricultural activities.
\end{abstract}

Keywords: anthropic pressure, Histosol, hydromorphic soils, organic matter

\section{Introduction}

Savanna is the term that refers to areas with open vegetation and which shelters typical plant species, formed by grasses, with sparse presence of small trees and shrubs. This term is used to designate the open vegetation of Roraima, of the Amazon biome, which is part of the "Guiana savannas" ecoregion, and is associated to a set of geological and geomorphological characteristics with physical, ecological, and floristic specificities, which distinguish it from cerrados (savanna) from other parts of Brazil (Almeida, 2016; Barbosa \& Miranda, 2005; Barbosa, Campos, Pinto, \& Fearnside, 2007; Bastos \& Ferreira, 2010; T. M. Carvalho, C. M. Carvalho, \& Morais, 2016). Savana is an ecosystem that is fragile and susceptible to the impact of human occupation and the use of fire (Furley, 2010; Soares et al., 2015; Zinck, 2011).

In the Amazon, the savannas comprise lands of Brazil, Guyana, and Venezuela, occupying $61,664 \mathrm{~km}^{2}, 43,358$ $\mathrm{km}^{2}$ of which are located in the Brazilian territory (Barbosa \& Miranda, 2005). The savannas of Roraima, in the extreme North of the Amazon, form the largest portion in a continuous area, belonging to the landscape of the Guiana savanna ecoregion, whose area corresponds to $19.30 \%$ of the State, designated locally of "lavrado" 
(Morais \& Carvalho, 2015). About $1 \%$ of the savanna area is covered by bodies of water, mountain refuges, and buriti palm tree, which, despite the small representativeness within the savannas, have unique functions and characteristics, contributing to the maintenance of water resources and transit of different animal and vegetable species (Barbosa et al., 2007).

One of the prominent features of the savanna is the hydrography formed by lakes and lentic environments, which, due to the accumulation of rainwater and the upwelling of groundwater, form drainage systems through which water flows, originating the buriti riparian (Bríglia-Ferreira, Röpke, \& Alves-Gomes, 2012; Meneses, Costa, \& Costa, 2007). The buriti (Mauritia flexuosa L.) riparian are lotic, shallow aquatic environments with a large amount of organic matter accumulated due to the presence of aquatic plants, such as cyperaceae and herbaceous plants, as well as lowland grasses (Matos, Nunes, Silva, \& Oliveira, 2014). These formations of buriti palm tree lane can be distributed linealy along with drainage channels, creek (igarapés) or grouped, associated to the paleochannels (terraces) of rivers (Carvalho et al., 2016).

In Brazil, the areas of lakes and riparian of buriti palm tree are of permanent preservation (APP), which aim at the integrity of natural resources and maintenance of environmental sustainability, according to Law No. 12.651 (Brazil, 2012).

The soils of lake environments and buriti riparian of the Roraima savanna are hydromorphic, since in natural conditions they are poorly drained, saturated by water permanently or for a certain period of the year. Due to the water stagnation, the soils in these conditions present horizons with greyish and yellowish coloring, a characteristic of the Inceptsol (Gleysols). In addition, the accumulation of vegetal residues, responsible for the elevation of the organic matter content, gives rise to the histic horizon, which presents black, gray, or very dark coloration, characteristic of Hystosol (Vale Júnior \& Schaefer, 2010).

The formation of Hystosol (peatlands) in these environments results from an imbalance between the accumulation and decomposition of organic materials whose deposition rate exceeds the decay rate, which is caused by insufficient or low biological activity as a consequence of adverse environmental factors, basically excessive acidity, in addition to saturation by water for a long time, establishing anoxic conditions. In tropical lowlands, fluctuation of groundwater level, controlled by rainfall and evapotranspiration, has an important effect on the formation of peats, especially in forest swamps (Ludang, Jaya, \& Inoue, 2007).

Studies estimate the areas of peatlands in the Amazon around 150,000 $\mathrm{km}^{2}$, suggesting a great contribution of these environments to the global carbon (C) cycle, compared with other environments of the globe (Lähteenoja, Ruokolainen, Schulman, \& Oinonen, 2009). Peatlands are defined as wetlands, where $80 \%$ of the area is covered by Hystosol, whose existence is a function of vegetation cover and water conditions (FAO, 1974). In these environments, anaerobic decomposition determines the type of soil organic matter (SOM) together with soil chemical conditions, weathering agents, biological nutrient cycling, and biogenic mineral production (Driessen, Deckers, Spaargaren, \& Nachtergaele, 2001; Kelly, Chadwick, \& Hilinski, 1998). Soil organic matter plays an important role in the biogeochemistry and ecology of streams, rivers, and lakes (Winterdahl et al., 2011) and is part of the global $\mathrm{C}$ cycle as a vector for transporting $\mathrm{C}$ from the terrestrial to aquatic and marine environments, followed by sedimentation and remineralization (Cole et al., 2007). Variations in vegetation structure evolve in response to peatland changes over time, so that tropical peat vegetation is not uniform (Page et al., 2004). However, little attention has been given to these types of environmental compartment, despite its importance in the global biogeochemical C cycle (Inubushi et al., 2003; Neue, Gaunt, Wang, Becker-Heidmann, \& Quijano, 1997).

Anthropic interferences, whether for agricultural reasons or urbanization, in ecosystems with occurrence of Hystosol, alter the dynamics of organic matter, with reduction in the content and changes in quality over time (Stevenson, 1994; Zinck, 2011). The use and management practices of agricultural systems interfere in the natural balance of the processes of pedogenesis in the Hystosol, accelerating losses of $\mathrm{C}, \mathrm{N}, \mathrm{K}$, and many other nutrients, thus altering chemical attributes and the relationships between humic substances (Pereira, Ebeling, Valladares, Anjos, \& Espíndula Júnior, 2006), besides promoting the lowering of the superficial level, the phenomenon of subsidence (Valladares, Pereira, Anjos, \& Ebeling, 2008).

In many scenarios, buriti riparian are springs, or drainage headwaters, that feed the watercourses that evolve into rivers. Its vegetation accompanies this evolution, promoting a natural vegetative gradient, which begins with buritis and progresses to the formation of riparian forest, as occurs in the Cerrado biome of Central Brazil (Pivello \& Coutinho, 1996), which function as ecological corridors.

These transition zones that separate well-drained clays linking pediplanes and aquatic systems aim at intercepting highland nutrients (such as nitrogen, phosphorus, and organic matter) and contaminants, including 
heavy metals and organic pollutants (Vidon et al., 2010), filtering sediments (Kirkkala, Ventelä, \& Tarvainen, 2012).

Information about soils with histic horizons of buritis and lake environments, which make up the savannas of the northern Amazon, is scarce, justifying studies that generate such information to promote the understanding of the chemical reactions in these environments and relations with physical, chemical, and biological attributes, promoting an understanding of the environmental services that these environments can exert.

In this context, the evaluation of soil chemical attributes in environments of lakes and buriti palm riparian that are under anthropic pressure is extremely important to know more deeply these environments and contribute to the monitoring of the changes that may occur, providing subsidies for the establishment of policies and actions that aim to contribute to the maintenance of the existence of these ecosystems in a sustainable way. Thus, the objective of this study was to characterize the chemical attributes of soils with a histic horizon of lakes and buriti riparian in the savannas in the Upper Rio Branco Basin, in the northern Amazon, and relate the results to the type of anthropization.

\section{Materials and Methods}

\subsection{Study Environments}

The study environments are APP located in the municipality of Boa Vista, in the state of Roraima, Brazil, in the northern part of Amazonia, at the geographical coordinates $2^{\circ} 39^{\prime} 24^{\prime \prime}$ and $2^{\circ} 56^{\prime} 05^{\prime \prime} \mathrm{N}$, and $60^{\circ} 51^{\prime} 01^{\prime \prime}$ and $60^{\circ} 32^{\prime} 25^{\prime \prime} \mathrm{W}$ (Figure 1).

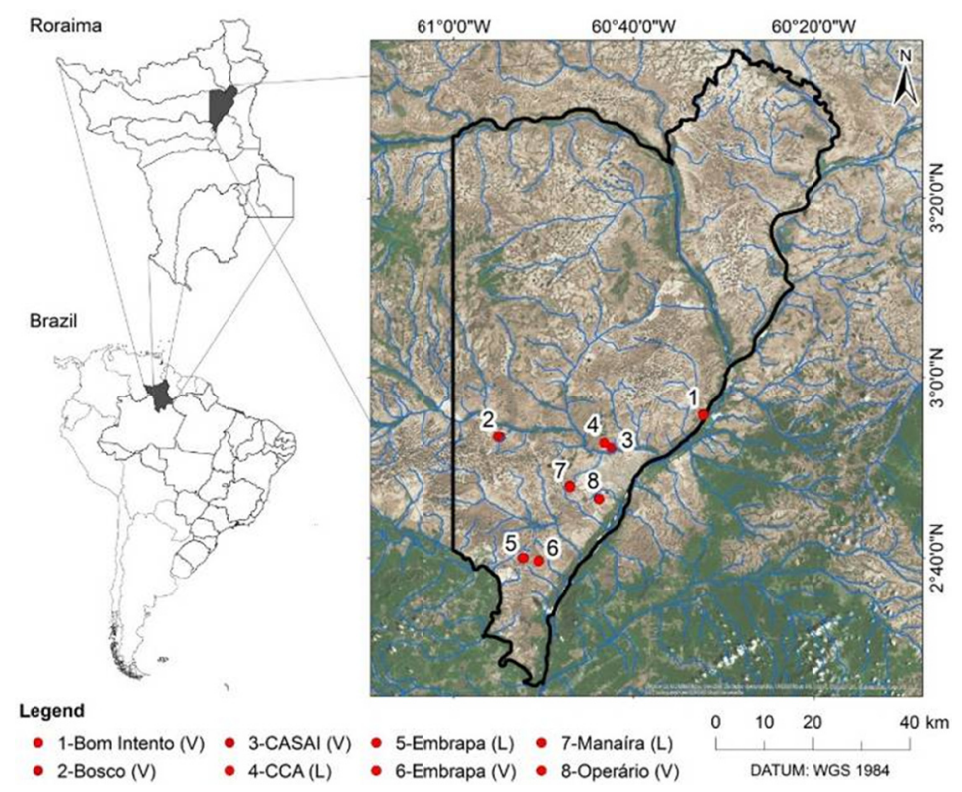

Figure 1. Location of study environments

\subsection{Characterization of Study Environments}

The study environments, consisting of three lakes (4-CCA, 5-Embrapa, and 7-Manaíra) and five buriti riparian (1-Bom Intento, 2-Bosco, 3-Casai, 6-Embrapa, and 8-Operário), are included in the Boa Vista formation domain, whose relief varies from plane to gently undulating, with an altitude varying from 80 to $100 \mathrm{~m}$, forming an extensive planation surface, elaborated during a long dry climatic phase in the lower and medium Pleistocene (Brazil, 1975), inserted in the Pediplane of Rio Branco-Rio Negro (Meneses et al., 2007).

The climate is tropical humid (Aw, according to the Köppen classification system), with rains during summer (April to September), with annual average rainfall around $1,750 \mathrm{~mm}$. The dry period (October to March) presents precipitation around $60 \mathrm{~mm}$ in the driest month and annual average temperature of $27.4{ }^{\circ} \mathrm{C}$ (Araújo et al., 2001).

In the studied environment, a savanna vegetation is found in the lakes, largely of grasses and cyperaceae, interspersed with shrubby vegetation such as murici (Byrsonima ssp.), and in environments of buriti riparian with 
pioneer formations, the characteristic botanical species is buriti (Mauritia flexuosa L.) (Barbosa \& Miranda, 2005; Benedetti, Vale Júnior, Schaefer, Melo, \& Uchôa, 2011; Meneses et al., 2007; Miranda \& Absy, 1997).

The soils are characterized as hydromorphic, since the buriti riparian and lakes are environments saturated by water for a long period of the year, with a thick organic layer (histic horizon), being classified as Organossolo and Gleissolo (Brazilian System of Soil Classification, Santos et al., 2013) corresponding to Histosol and Inceptisol (USA taxonomy) Histosol and Gleysol (WRB), respectively, resulting from high accumulations of plant residues, with varying degrees of decomposition (Santos et al., 2013).

\subsection{Collection and Preparation of Soil Samples}

Soil samples were collected in the 0.0-0.1, 0.1-0.2, 0.2-0.3, 0.3-0.4, and 0.4-0.5 m depth layers in five buriti riparian and three lakes, considering the differences of environmental features within the study areas, with three replicates at each collection point, spaced $100 \mathrm{~m}$ apart. In the buriti riparian, samples were collected at a distance of $5 \mathrm{~m}$ from the water course and, in the lakes, a transept was made, starting $10 \mathrm{~m}$ from the border passing through the center during the dry season of the lakes. Deformed samples were collected in PVC pipes $(0.70 \times$ $0.30 \mathrm{~m}$ ) because the saturation conditions by water does not to allow the opening of trench below $0.30 \mathrm{~m}$ depth. After removal of the coarse root fractions, the samples were air-dried, crushed, and passed through 2-mm mesh sieves.

\subsection{Soil Chemical Characterization}

The chemical characterization of soils occurred according to Silva (2009). The $\mathrm{pH}$ was determined in water $(1: 2.5, \mathrm{v} / \mathrm{v})$. Potential acidity $(\mathrm{H}+\mathrm{Al})$ was determined by extraction with $0.5 \mathrm{~mol} \mathrm{~L}^{-1}$ calcium acetate solution at pH 7.0. Exchangeable aluminum, calcium, and magnesium were extracted with $1.0 \mathrm{~mol} \mathrm{~L}^{-1} \mathrm{KCl}$ solution. The $\mathrm{Al}^{3+}$ was quantified by acid-base titration with $0.025 \mathrm{~mol} \mathrm{~L}^{-1} \mathrm{NaOH}$ solution. Exchangeable $\mathrm{Ca}$ and $\mathrm{Mg}$ were quantified by complexometric titration with $0.0125 \mathrm{~mol} \mathrm{~L}^{-1}$ EDTA. Available $\mathrm{P}$ and $\mathrm{K}$ were extracted with acid double solution $\left(0.05 \mathrm{~mol} \mathrm{~L}^{-1} \mathrm{HCl}+0.0125 \mathrm{~mol} \mathrm{~L}^{-1} \mathrm{H}_{2} \mathrm{SO}_{4}\right), \mathrm{K}$ determined by flame photometry and $\mathrm{P}$ by UV-visible molecular spectrophotometry. The sum of bases (SB), total cation exchange capacity (CTC), base saturation (V), and aluminum saturation $(\mathrm{m})$ were calculated from the results obtained. Total organic carbon (TOC) was quantified by dry combustion on Perkin Elmer elemental analyzer series II 2400.

\subsection{Statistical Analysis}

The data were subjected to descriptive statistical analysis, represented in boxplot graphs, and the multivariate analysis. Principal Component Analysis (PCA) was used to determine the correlation between chemical attributes and collection sites (lake and buriti riparian), and between environments. In all analysis the software $\mathrm{R}$ 3.4 (R Core Team, 2017) was used in conjunction with the ExpDes.pt, factoextra, and FactoMineR packages (Ferreira, Cavalcanti, \& Nogueira, 2018; Kassambara \& Mundt, 2017; Lê, Josse, \& Husson, 2008).

\section{Results and Discussion}

\subsection{Chemical Characterization of Soils in Lakes and Buriti Riparian}

Values of $\mathrm{pH}$ in $\mathrm{H}_{2} \mathrm{O}$ were low in the two environments evaluated (Figure 2). In the lakes, the pH values ranged from 4.42 to 4.74 , and in the buriti riparian, from 4.13 to 4.82 . In terms of acidity, the environments did not present expressive variations but indicated very acidic soils. However, these environments were less acidic than the peatland soils studied by Zinck (2011) in the savannas of Venezuela and Guyana. These environments, in terms of acidity, resemble the dryland soils of the savannas of the northern Amazonia, studied by Benedetti et al. (2011) and Feitosa, Vale Júnior, Schaefer, Sousa, \& Nascimento (2016). This high acidity results from the advanced weathering of savanna soils, characteristic of tropical regions and low levels of bases. These values corroborate Valladares et al. (2008), which are the result of both the nature of plant material and of soil origin material, as opposed to soils of temperate regions with high base saturation (V), enriched by limestone and moss vegetation and swamp environments (Grozav \& Rogobete, 2012).

The values of $\mathrm{Al}^{3+}$ in the lakes ranged from 0.75 to $2.66 \mathrm{cmol}_{\mathrm{c}} \mathrm{kg}^{-1}$ (Figure 2B), whereas those of buriti riparian varied from 0.50 to $7.95 \mathrm{cmol}_{\mathrm{c}} \mathrm{kg}^{-1}$. The higher values in buriti riparian are attributed to higher organic matter contents. The Casai and Bom Intento riparian had $\mathrm{Al}^{3+}$ values higher than $4 \mathrm{cmol}_{\mathrm{c}} \mathrm{kg}^{-1}$, which indicate an alitic character and higher toxicity (Sousa, Miranda, \& Oliveira, 2007). The values found are below the Inceptsol (Gleysol) of the savanna of Roraima (Benedetti et al., 2011) and soils of buriti riparian of the southeastern region of Brazil (Guimarães, Araújo, \& Corrêa, 2002).

The values of potential acidity $(\mathrm{H}+\mathrm{Al})$ were higher in the palm swamps than in the lakes (Figure 2C). According to Zinck (2011), the high values of potential acidity are related to the $\mathrm{pH}$ dependent surface load of 
the humic substances, with $\mathrm{H}^{+}$strongly bound in the carboxyl and hydroxyl functional groups that behave like weak acids. The $\mathrm{H}+\mathrm{Al}$ values of the present study are higher than those obtained by Fonseca (2017) and Sousa, Brasil, Figueiredo, \& Leandro (2015) and compatible with those reported by Bispo et al. (2015).

In both evaluated environments (lakes and buriti riparian), the $\mathrm{Ca}^{2+}$ and $\mathrm{Mg}^{2+}$ contents were low, but variations occur between the environments (Figures 2D and 2E). The values obtained in the samples from the lakes were higher than in the buriti riparian. In peat soils of Venezuela, Zinck (2011) verified this variation in $\mathrm{Ca}^{2+}$ and $\mathrm{Mg}^{2+}$ contents attributed to the probable permanence of these nutrients in the soil due to the formation of complexes with the organic matter. In the studied environments, these higher values in the lake environment may be justified by the fact that the CCA lake is an area of sediment accumulation from the Apoteri balsatic formation, keeping the values of these elements elevated by promoting differences between the environments. In general, the $\mathrm{Ca}^{2+}$ and $\mathrm{Mg}^{2+}$ values in this study were higher than those obtained by Sousa et al. (2015).

In relation to the $\mathrm{K}^{+}$contents (Figure $2 \mathrm{~F}$ ), the highest levels in the palm swamp environments may be associated with partially decomposed vegetation and flooded environment for a given period, which contributes to the input of these ions to the soil (Bispo et al., 2015; Cipriano-Silva, Valladares, Pereira, \& Anjos, 2014).
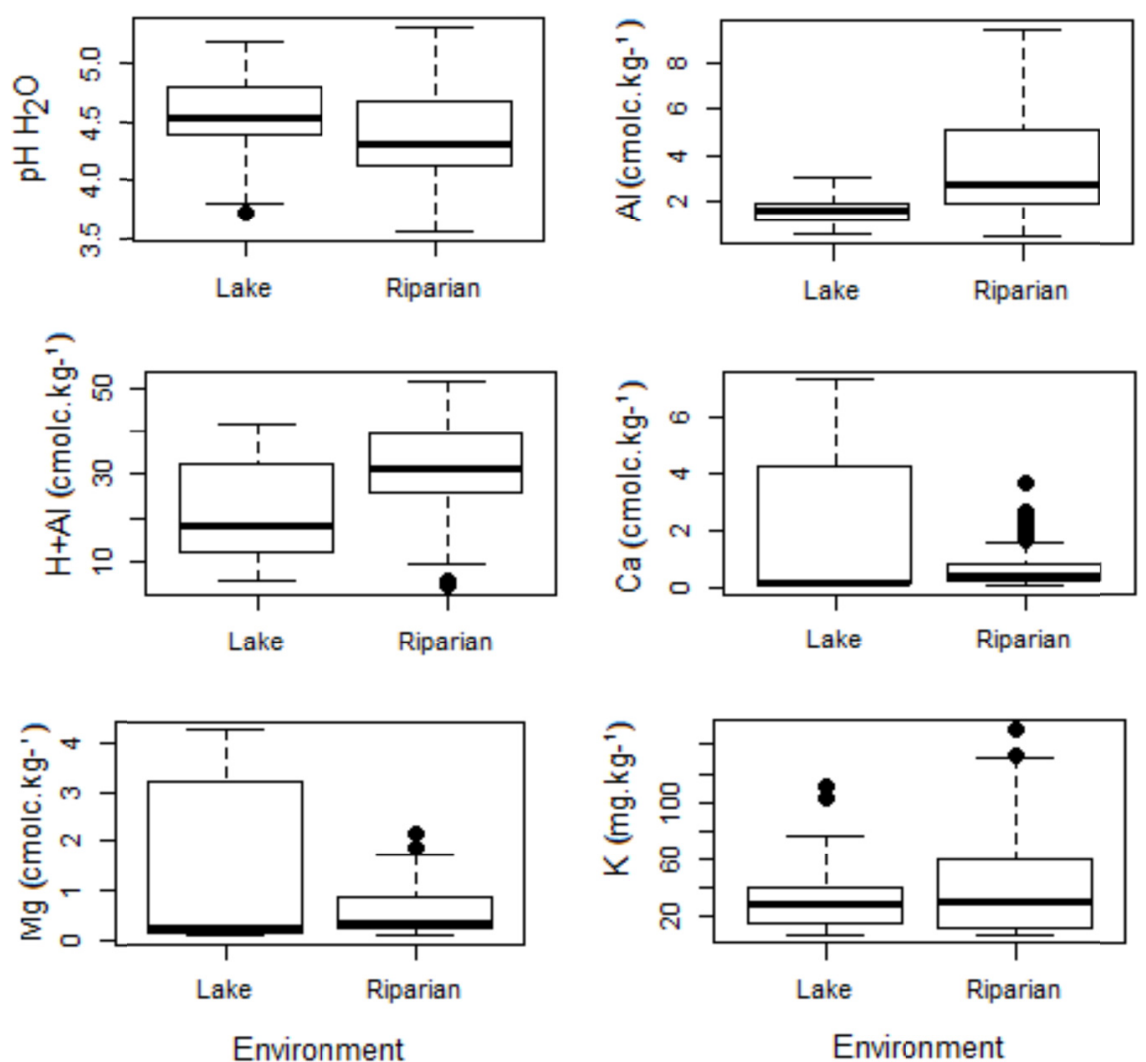

Figure 2. Chemical characterization of soils of lakes and buriti riparian, $\mathrm{pH}$ in $\mathrm{H}_{2} \mathrm{O}, \mathrm{Al}^{3+}, \mathrm{H}+\mathrm{Al}, \mathrm{Ca}^{2+}, \mathrm{Mg}^{2+}$, and $\mathrm{K}^{+}$in the savanna region of Boa Vista, Northern Amazonia, Brazil 

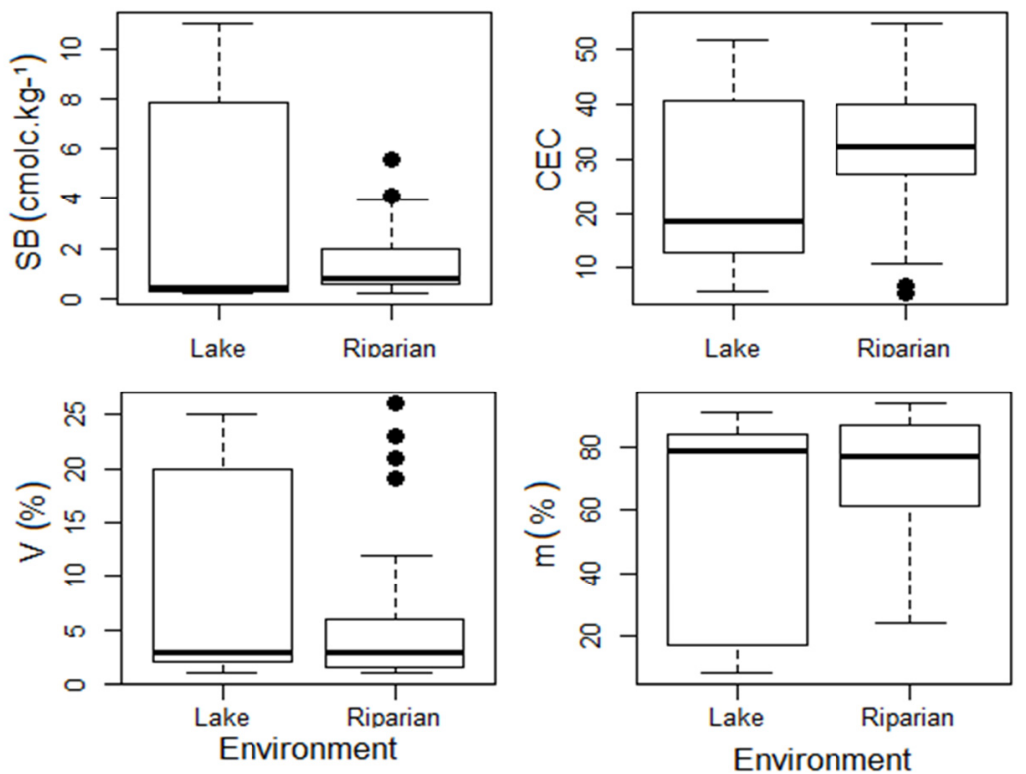

Figure 3. Sum of bases (SB), cation exchange capacity (CEC), base saturation (V), and aluminum saturation (m) of lakes and buriti riparian environments, in the savanna region of Boa Vista, Northern Amazonia, Brazil

For the SB (Figure 3), the values are low in both environments and are linked to low $\mathrm{Ca}, \mathrm{Mg}$, and $\mathrm{K}$ contents in soils and source material, as was also observed in soils with peats of Guyana and Venezuela (Zinck, 2011). However, the results of this study are higher than those obtained for organic soils in southeastern Brazil, in studies conducted by Bispo et al. (2015), and for Amazon soils by Feitosa et al. (2016).

For the total cation exchange capacity (CEC), there were variations between lake and buriti riparian environments. The values obtained in this work are higher than those of Bispo et al. (2015), Feitosa et al. (2016) and Sousa et al. (2015). High CEC values in organic soils are attributed to high $\mathrm{H}+\mathrm{Al}$ values, which can be attributed both to the quantity and quality of organic matter. While SB and V values (Figure 3) are very low, they reflect the losses occurred by weathering and exit of bases by the tropical climate conditions. The base saturation in the two environments is very low, mainly in the palm swams, which characterizes the soil as dystrophic (Santos et al., 2013). Nevertheless, the values of the two environments are higher than those obtained for peat soils of Guayana and Venezuela (Zinck, 2011) and Histosol of the buriti riparian studies carried out by Bishop et al. (2015) and Guimarães et al. (2002), both in the state of Minas Gerais, Brazil. When compared to dryland savanna soils obtained by Feitosa et al. (2016), these values are lower.

In relation to the aluminum saturation $(\mathrm{m})$ in the environments of lakes and buriti riparian, the values are mostly above 50\% (Santos et al., 2013), which can characterize the soils of these environments as alitic, with Al toxicity.

In the buriti riparian, TOC contents were higher than in lakes (Figure 4). Regardless of the environment, the results obtained for TOC were higher than the peat soils of Minas Gerais, Brazil (Bispo et al., 2015). The levels of available $\mathrm{P}$ were higher in buriti riparian environments when compared with lakes. These data were also higher than those observed in dryland soils of the Roraima savanna (Benedetti et al., 2011). These results show that the increase of phosphorus in these environments is due to anthropic actions, such as agricultural and urban activities with disposal of residues rich in phosphorus, contributing to increase the available $\mathrm{P}$ in the studied environments. The data from this study were lower than the results obtained by Zink (2011) for peatlands from Guayana and Venezuela. However, they were higher than those obtained for the peatlands of Minas Gerais, Brazil, studied by Bispo et al. (2015). 

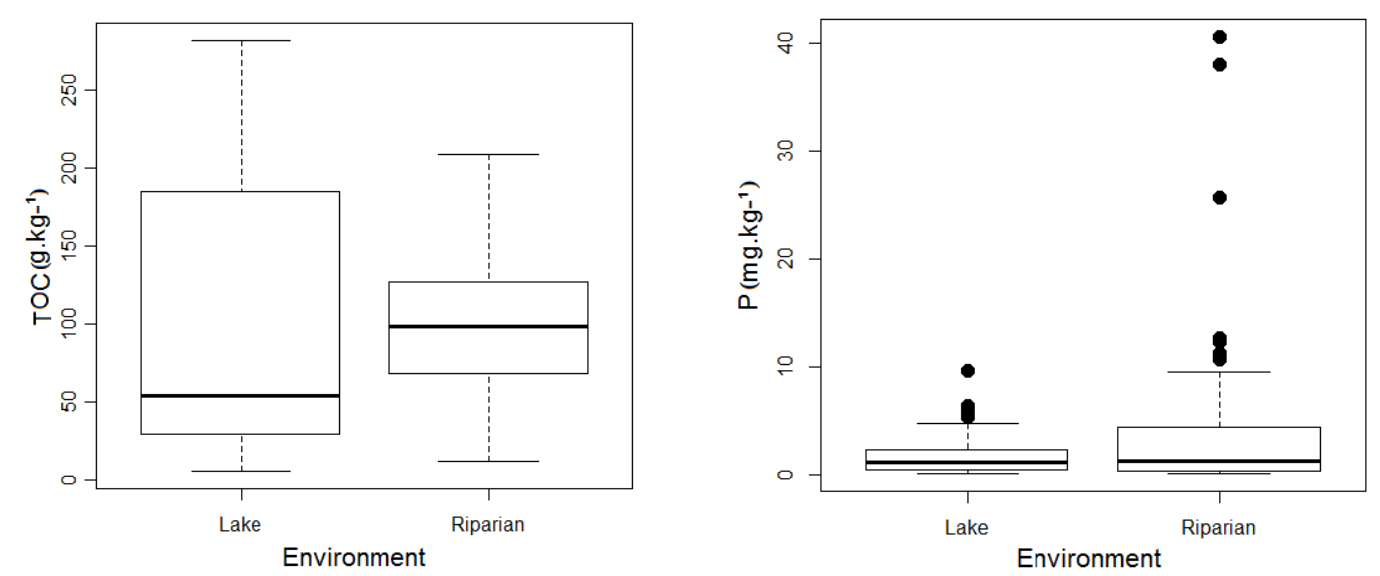

Figure 4. Mean values of total organic carbon (TOC) and available phosphorus (P) from the lakes and buriti riparian environments in the savanna region of Boa Vista, Northern Amazonia, Brazil

In general, the available $\mathrm{P}$ values are low, indicating low availability of $\mathrm{P}$ to plants, which may be associated with the natural soil poverty and the high capacity of $\mathrm{P}$ complexation by the organic matter, thus evidencing the reality of the soil of Roraima savannas that are characterized as dystrophic, with low levels of available $\mathrm{P}$ (Beneditti et al., 2011). In soils with high organic matter content, with high load availability, P is associated with organic compounds of high molecular weight forming poorly soluble compounds, since $\mathrm{P}$ can be bound to compounds of high molecular weight, forming phosphate-ester-amino acids with humic substances and may be complexed with humus, Fe, and Al (Andriesse, 1988; Bedrock et al., 1995; Brannon \& Sommers, 1985). These environments are considered as oligotrophic, similar to the peatland environments of Guayana and Venezuela, studied by Zinck (2011). It was also observed that the highest levels of available P were found in the buriti riparian environments, in the 0.00-0.10 m layer (Figure 5), decreasing in depth in all environments. Higher available $\mathrm{P}$ levels in the Bom Intento buriti riparian may be attributed to the influence of the waters of Rio Branco, which deposits P-rich sediments from rice fields and watermelon cultivation with bovine manure and mineral fertilization upstream the study area.

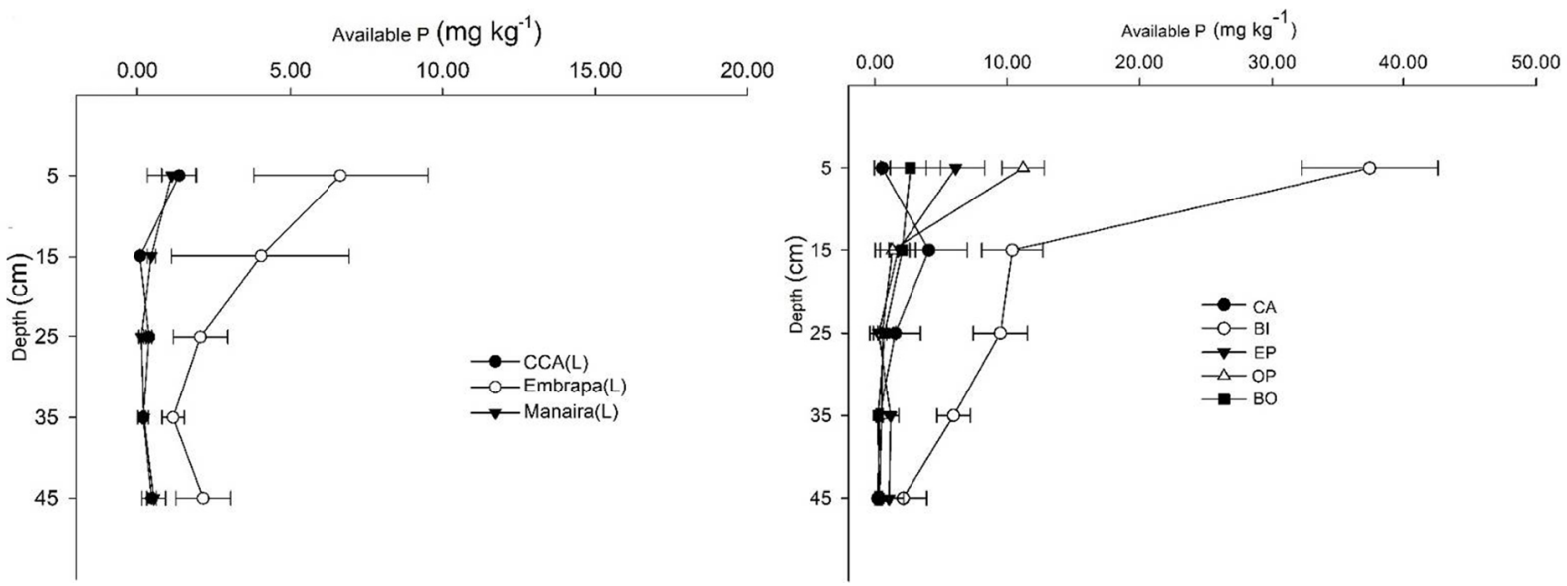

Figure 5. Mean levels of available phosphorus $(\mathrm{P})$ in depth in lake $(\mathrm{L})$ and buriti riparian environments (CA: Casai, BI: Bom Intento, EP: Embrapa, OP: Operário, and BO: Bosco riparians), in the savanna of the Northern Amazon, Brazil

\subsection{Soil Chemical Characterization in Lake Environments}

In the Embrapa lake, the higher $\mathrm{Al}^{3+}$ content and, consequently, higher saturation by $\mathrm{Al}^{3+}$, reflect in the lower base saturation (V) (Figure 6). In the CCA lake, there was lower $\mathrm{Al}^{3+}$ content and higher $\mathrm{V}$, with higher homogeneity in terms of $\mathrm{pH}$ distribution and higher values of $\mathrm{Ca}^{2+}, \mathrm{Mg}^{2+}$, and $\mathrm{K}^{+}$. The high values of $\mathrm{H}+\mathrm{Al}$ are 
results of the deprotonation of $\mathrm{H}^{+}$of the structures of humic substances, since this environment has a higher TOC content, about four times more than the other lake environments. The CCA lake has a hydrological behavior different from the other lakes, because it remains saturated by water during almost all the year, with a small dry phase during the most critical period of rain. This lake also receives sediments from the Apoteri formation (basaltic rocks), richer in $\mathrm{Ca}$ and $\mathrm{Mg}$, while Embrapa and Manaíra lakes remain dry for a longer period throughout the year and receive pre-weathered tertiary sediments from the Boa Vista formation.
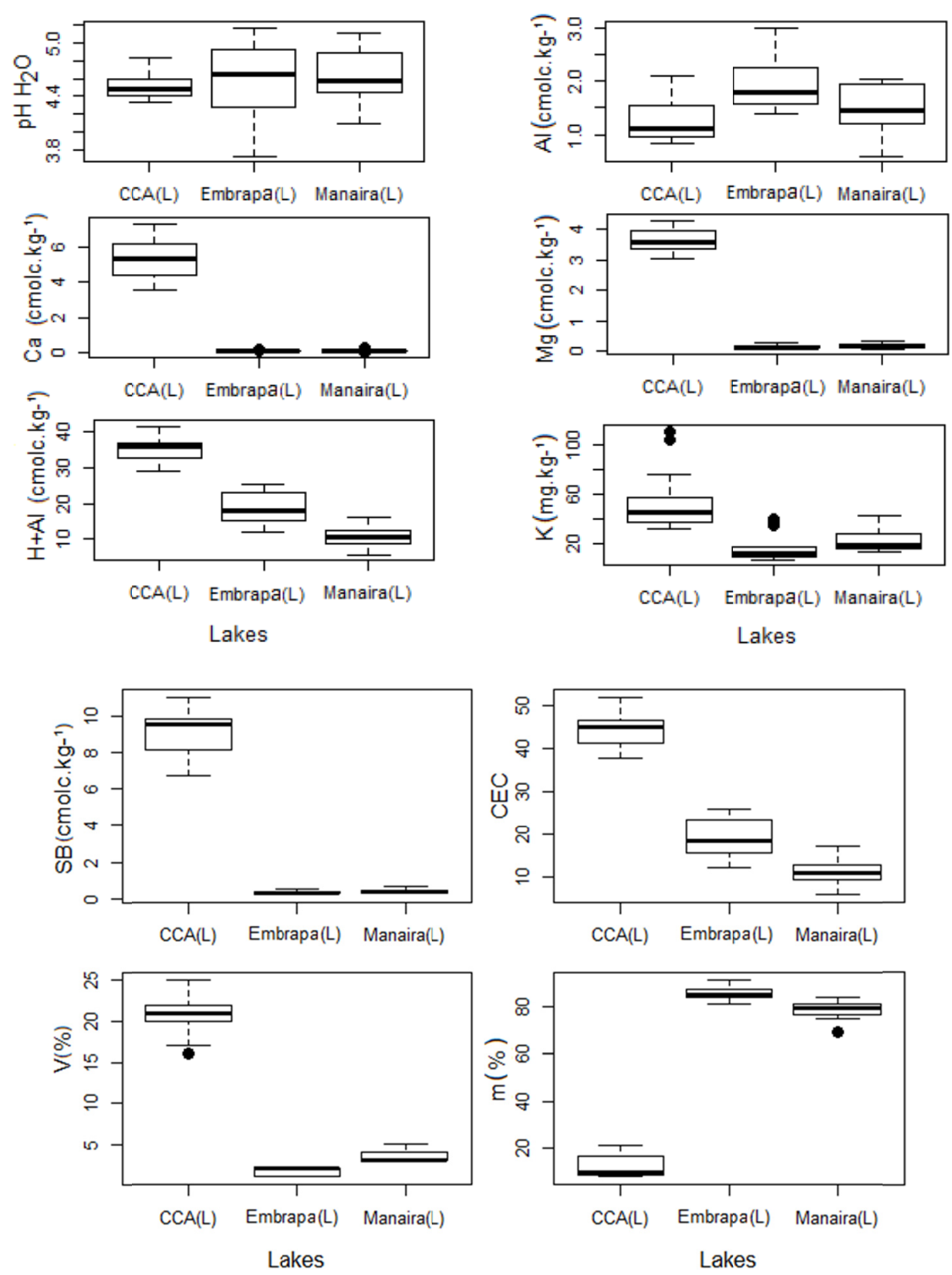

Figure 6. Mean contents of the chemical attributes of soils in the lake (L) environment, in the savanna of the Boa Vista region, Northern Amazonia, Brazil

\subsection{Chemical Characterization of Soils in Buriti Riparian Environments}

Among the studied buriti riparian, Bom Intento (BI) presented the highest levels of $\mathrm{Al}^{3+}$ and saturation by $\mathrm{Al}$, with lower values of $\mathrm{V}$ (Figure 7). The highest values of CEC (Figure 7) can be attributed to the high values of $\mathrm{H}$ + Al. On the opposite side is the Operário riparian whose values of $\mathrm{pH}, \mathrm{Ca}$, and $\mathrm{Mg}$ were higher and, 
consequently, $\mathrm{V}$ values and SB. The highest values of nutrients that occur in the Operário buriti riparian can be attributed to the anthropic actions by the agricultural practices along the buriti riparian, with production of leafy vegetables, which may be contributing to the transport of nutrients to these environments, which are adsorbed to organic matter.
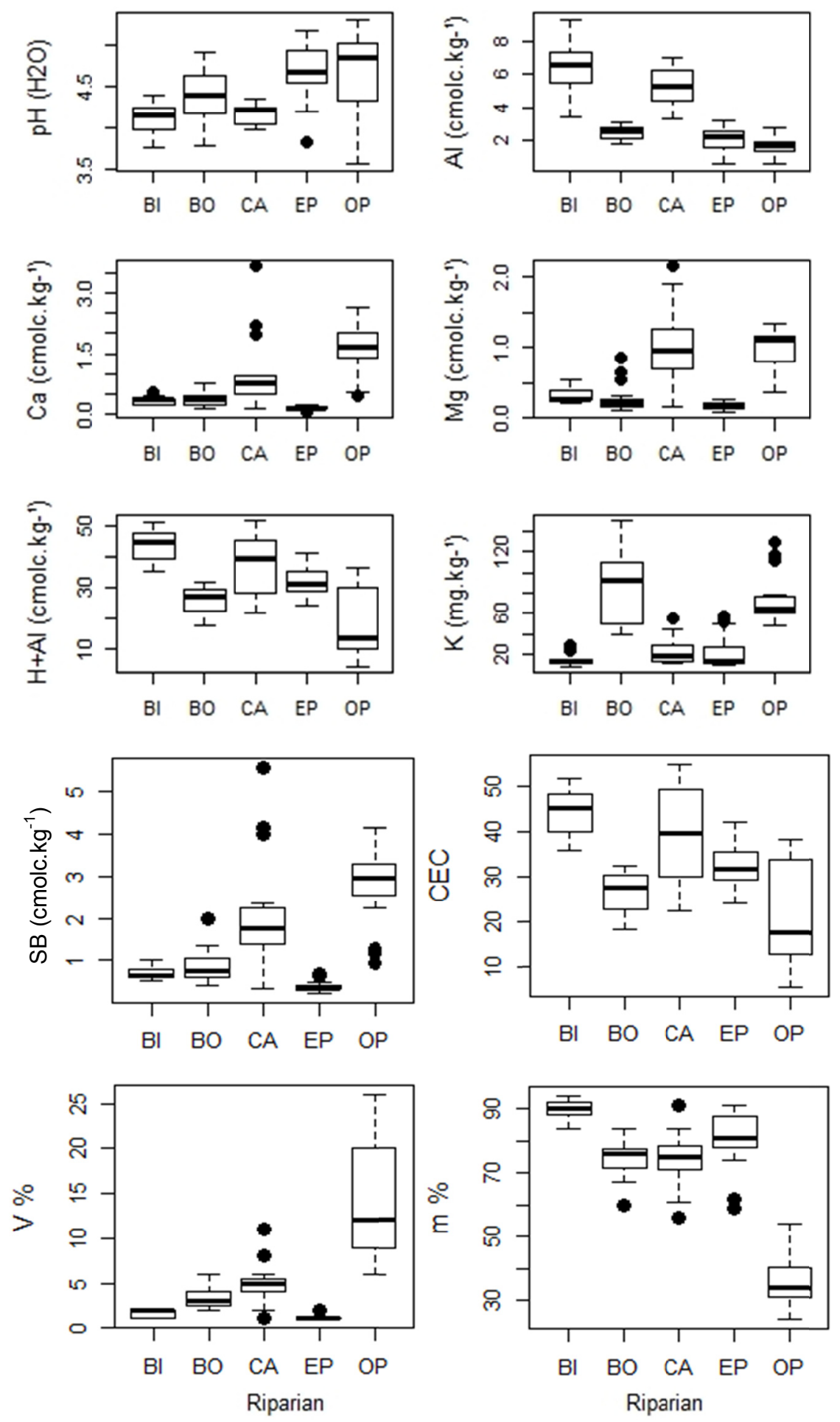

Figure 7. Mean contents of the chemical attributes of the soils of buriti riparian environments (CA: Casai, BI: Bom Intento, EP: Embrapa, OP: Operário, and BO: Bosco riparians), in the savanna of northern Amazon, Brazil 


\subsection{Available Phosphorus and Total Organic Carbon Between Lake and Buriti Riparian Environments}

The CCA lake has the lowest levels of available P (Figure 8) and the highest TOC content. This result in relation to $\mathrm{P}$ is in agreement with Novais, Smyth, and Nunes (2007), who stated that humic substances block the adsorption centers of the mineral colloids of the soil, decreasing the P adsorption capacity. The Embrapa lake presented the highest levels of $\mathrm{P}$, which may be related to soil genesis, with a sandy texture and no evidence of any source of $\mathrm{P}$ to the soil. The location of the lake close to experimental areas of agronomic research may be contributing to increasing of $\mathrm{P}$ as a function of its transport through runoff waters.

For the buriti riparian environments, the Bom Intento (BI) has the highest available P content (Figure 8). In addition, by analyzing the TOC content, this buriti riparian also presents the highest $\mathrm{C}$ content $\left(\mathrm{g} \mathrm{kg}^{-1}\right)$. This directly proportional relationship between total organic $\mathrm{C}$ content and organic $\mathrm{P}$ content contrasts with the values obtained by Novais et al. (2007), who concluded that the organic matter blocks the soil adsorption centers, decreasing the $\mathrm{P}$ adsorption capacity. This may be related to the direct and indirect effects that SOM has on the availability of nutrients (Dick, Novotny, Dieckow, \& Bayer, 2009).

For buriti riparian environments, higher P and TOC contents were found in buriti riparian BI, which may be related to the indirect effects that SOM has on the availability of nutrients. The main loss process of SOM is the mineralization promoted by fungi and bacteria, and maintaining TOC content is fundamental to preserve the soil quality and its environmental functionality (Dick et al., 2009).
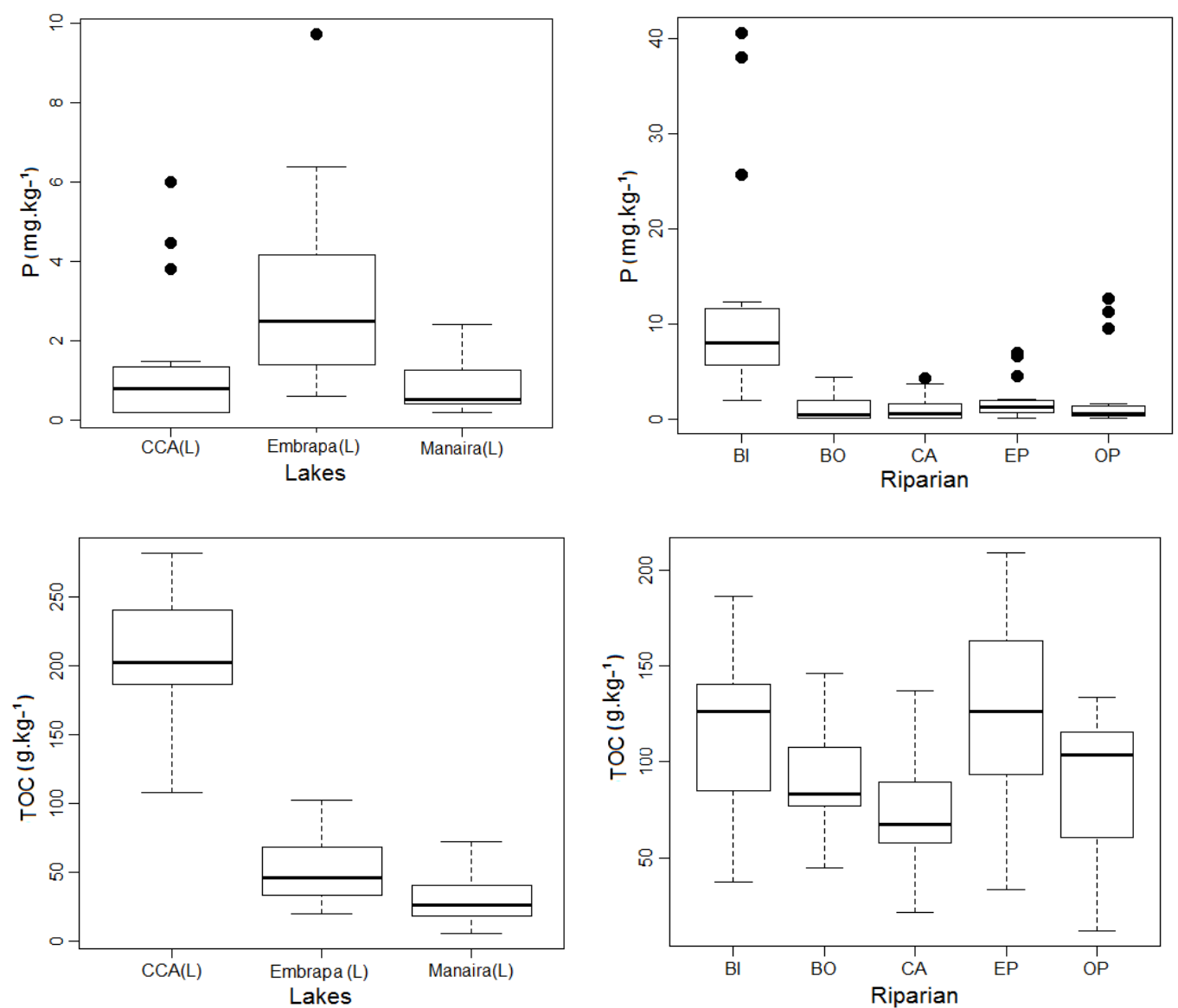

Figure 8. Mean values of available $\mathrm{P}$ and total organic carbon (TOC) in lakes and buriti riparian in the savanna of the Boa Vista region, Northern Amazonia, Brazil

\subsection{Principal Component Analysis (PCA)}

The principal components analysis (PCA) for the chemical attributes evaluated in the lakes and buriti riparian environments (Figure 9) explained $70 \%$ of the original variability of the data. The values of $\mathrm{K}^{+}, \mathrm{Mg}^{2+}, \mathrm{Ca}^{2+}, \mathrm{V}$, and $\mathrm{SB}$ contribute positively, and $\mathrm{Al}^{3+}, \mathrm{CEC}$, and $\mathrm{H}+\mathrm{Al}$ contribute negatively. The values of $\mathrm{Ca}^{2+}, \mathrm{Mg}^{2+}, \mathrm{V}$, and 
$\mathrm{SB}$ contribute to the lake environments. On the other hand, the values of $\mathrm{Al}^{3+}, \mathrm{H}+\mathrm{Al}$, and $\mathrm{CEC}$ define the buriti riparian environments. It is observed that the $\mathrm{CEC}$ values are a strong contribution of $\mathrm{Al}$ and $\mathrm{H}$ from organic matter.

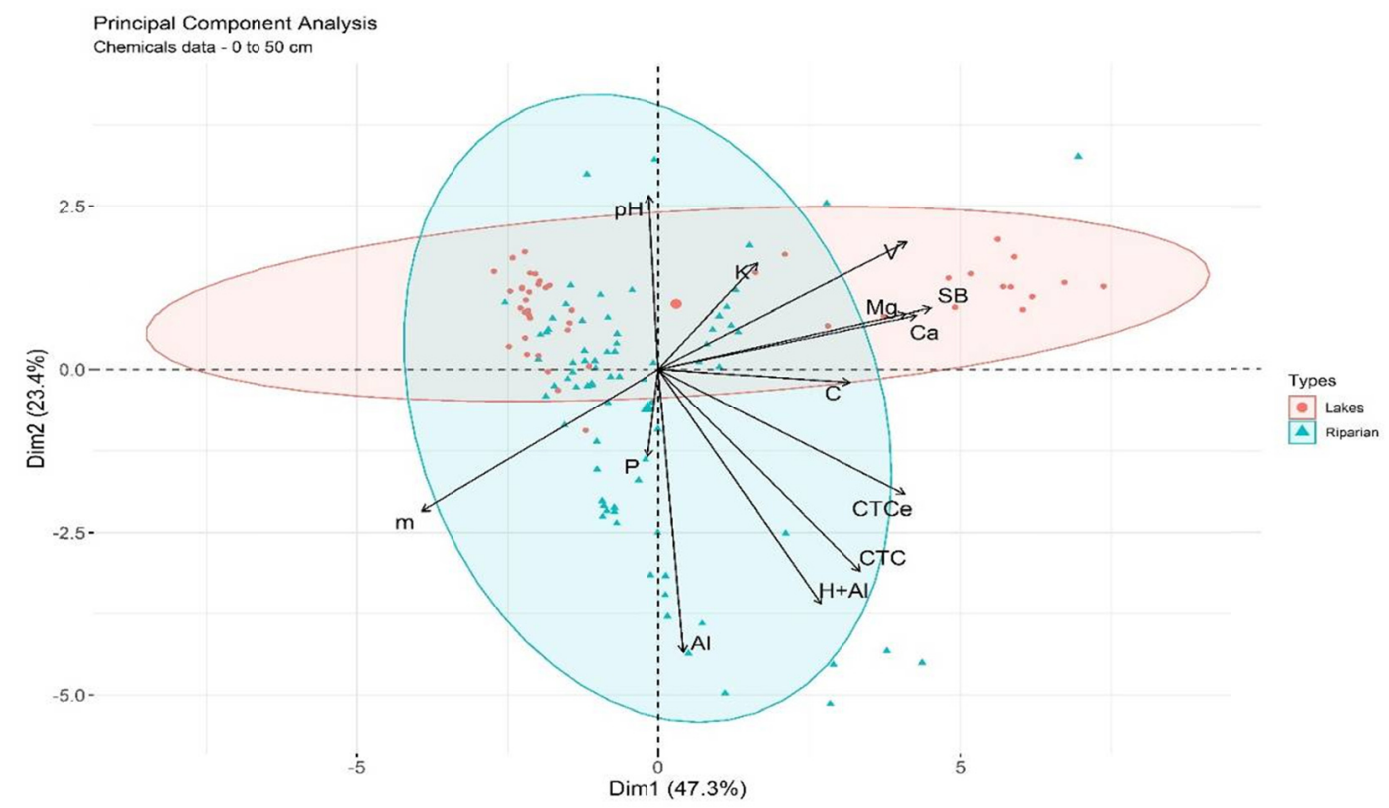

Figure 9. Principal component diagram showing the distribution of the environments (lakes and buriti riparian) according to chemical attributes

The results of the principal component analysis (PCA) for the chemical attributes evaluated in the environments (Figure 10) explain $70.7 \%$ of the original variability of the data retained in these components. A new set of variables (principal components) that explain the variation structure was evaluated, and the weight of each variable analyzed in each component (axes) was represented to minimize the loss of information.

The scores for analysis of principal components were done jointly for the different chemical parameters, only separated by layers, and independently for buriti riparian (Casai, Bom Intento, Embrapa, Operário, and Bosco) and lakes (Embrapa, Manaíra, and CCA) to find the interdependence of the chemical attributes studied.

In the components, the occurrence of two environments with very clear distinctions, CCA and Manaíra, was observed, the latter representing stage of extreme oligotrophism. For buriti riparian environments, a clear separation between Operário and Bom Intento can be observed, being similar only by the available P values. The other environments remained within a similarity sustained by the low levels of bases and high acidity values.

The second principal component (PC2) explained $23.4 \%$ of the variability of $\mathrm{P}$ and was strongly associated with the chemical attributes, contributing negatively to the $\mathrm{pH}$ value, which was the most affected. 


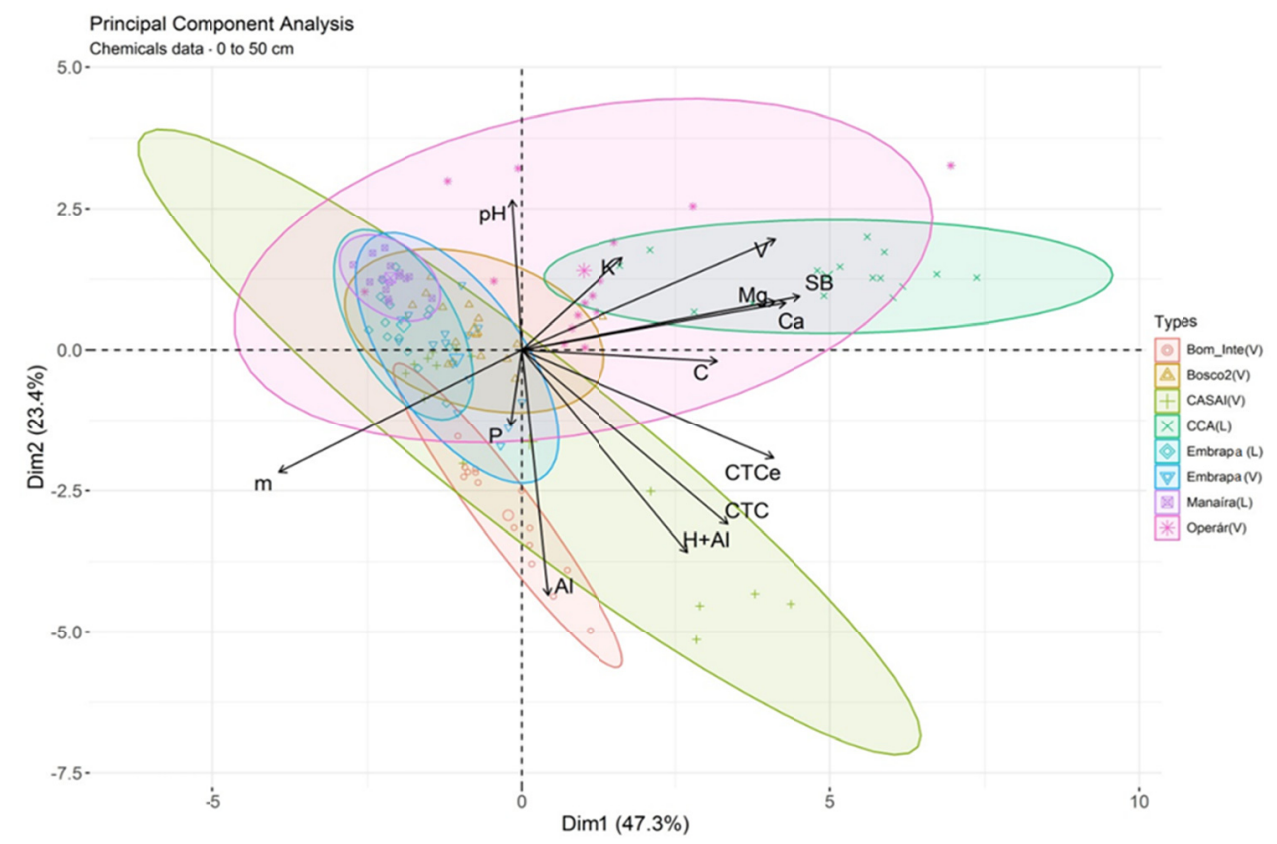

Figure 10. Principal component diagram showing the distribution of environments according to chemical attributes

\section{Conclusions}

The studies conducted for the observed environments concluded that the soils presented high acidity, low fertility, aluminum toxicity and high levels of organic carbon. The phosphorus contents of the environments of riparians were higher than those found in naturally oligotrophic soils, evidencing the effects of anthropic agricultural activities and urban expansion. In this sense, we consider that the Amazonian ecosystems of lakes and riparians have peculiarities, because they are critical areas for carbon conservation in the Amazonian soil, extrapolating their intrinsic value to the importance of biodiversity, which reinforces the need for control mechanisms in the preservation of these environments.

\section{References}

Almeida, I. R. S. (2016). Composição e estrutura trófica das assembleias de peixes em veredas de buritizais, no periodo de seca, no lavrado de Roraima, Brasil (Master's thesis, Instituto Nacional de Pesquisas da Amazônia, Universidade Estadual de Roraima, Manaus/Boa Vista, Brazil). Retrieved from http://bdtd.inpa.gov.br/bitstream/tede/2144/5/Disserta\%C3\%A7\%C3\%A3o\%20IRSA_GMS_JZ.pdf

Andriesse, J. P. (1988). Nature and management of tropical peat soils. FAO Soils Bulletin, 59. Rome, FAO. Retrieved from http://www.fao.org/docrep/x5872e/x5872e00.htm

Araújo, W. F., Andrade Júnior, A. S., Medeiros, R. D., \& Sampaio, R. A. (2001). Precipitação pluviométrica mensal provável em Boa Vista, Estado de Roraima, Brasil. Revista Brasileira Engenharia Agrícola e Ambiental, 5(3), 563-567. https://doi.org/10.1590/S1415-43662001000300032

Barbosa, R. I., \& Miranda, I. S. (2005). Diversidade de Savanas de Roraima. Ação Ambiental, 2, 19-23. Retrieved from http://repositorio.inpa.gov.br/handle/123/5850

Barbosa, R. I., Campos, C., Pinto, F., \& Fearnside, P. M. (2007). The "Lavrados" of Roraima: Biodiversity and Conservation of Brazil's Amazonia Savannas. Functional Ecosystems and Communities, 1, 29-41. Retrieved from http://repositorio.inpa.gov.br/handle/123/5972

Bastos, L. A., \& Ferreira, I. M. (2010). Composições fitofisionômicas do Bioma Cerrado: Estudo sobre o subsistema de vereda. Espaço em Revista, 12(1), 97-108, Retrieved from https://www.revistas.ufg.br/ espaco/article/view/17656/10487

Bedrock, C. N., Cheshire, M. V., Chudek, J. A., Fraser, A. R., Goodman, B. A. \& Shand, C. A. (1995). Effect of $\mathrm{pH}$ on precipitation of humic acid from peat and mineral soils on the distribution of phosphorus forms in 
humic and fulvic acid fractions. Communications in Soil Science and Plant Analysis, 26(9), 9-10. https://doi.org/10.1080/00103629509369381

Benedetti, U. G., Vale Júnior, J. F., Schaefer, C. E. G. R., Melo, V. F., \& Uchôa, S. C. P. (2011). Gênese, química e mineralogia de solos derivados de sedimentos pleistocênicos e de rochas vulcânicas básicas em Roraima, norte amazônico. Revista Brasileira de Ciência do Solo, 35(2), 299-312. https://doi.org/10.1590/S0100-06 832011000200002

Bispo, D. F. A., Silva, A. C., Christoforo, C., Silva, M. L. N., Barbosa, M. S., Silva, B. P. C., \& Barral, U. (2015). Characterization of headwaters peats of the rio Araçuí, Minas Gerais state, Brazil. Revista Brasileira de Ciência do Solo, 39(2), 475-489. https://doi.org/10.1590/01000683rbcs20140337

Brannon, C. A., \& Sommers, L. E. (1985). Stability and mineralization of organic phosphorus incorporated into model humic polymers. Soil Biology and Biochemistry, 17(2), 221-227. https://doi.org/10.1016/0038-0717 (85)90118-X

Brazil. (1975). Folha NA.20. Boa Vista e partes da folha NA.21. Tumucumaque, NB.20 e NB.21 (Geologia, geomorfologia, pedologia, vegetação e uso potencial da terra). Projeto Randambrasil. Rio de Janeiro, Ministério das Minas e Energia.

Brazil. (2012). Dispõe sobre a proteção da vegetação nativa; altera as Leis $\mathrm{n}^{\mathrm{os}} 6.938$, de 31 de agosto de 1981, 9.393, de 19 de dezembro de 1996, e 11.428, de 22 de dezembro de 2006; revoga as Leis $n^{\text {os }} 4.771$, de 15 de setembro de 1965, e 7.754, de 14 de abril de 1989, e a Medida Provisória no 2.166-67, de 24 de agosto de 2001; e dá outras providências. Lei $n^{\circ} 12.651$, de 25 de maio de 2012. Retrieved from http://www.planalto. gov.br/cciviL_03/_Ato2011-2014/2012/Lei/L12651.htm

Bríglia-Ferreira, S. R., Röpke, C. P., \& Alves-Gomes, J. A. (2012). Ictiofauna da região da Serra da Lua (Roraima, Brasil) e importância dos ambientes aquáticos de 'lavrado' no interflúvio das bacias dos rios Negro, Essequibo e Orinoco. In F. C. Scarlato, R. A. O. Evangelista, \& W. F. Araújo (Eds.), Amazônia: Terra e Água, degradação e desenvolvimento sustentável (pp. 187-208). Boa Vista, RR: Editora da UFRR.

Carvalho, T. M., Carvalho, C. M., \& Morais, R. P. (2016). Fisiografia da paisagem e aspectos biogeomorfológicos do lavrado, Roraima, Brasil. Revista Brasileira de Geomorfologia, 17(1), 93-107. https://doi.org/10.20502/rbg.v17i1.669

Cipriano-Silva, R., Valladares, G. S., Pereira, M. G., \& Anjos, L. H. C. (2014). Caracterização de Organossolos em ambientes de várzea do nordeste do Brasil. Revista Brasileira de Ciência do Solo, 38(1), 26-38. https://doi.org/10.1590/S0100-06832014000100003

Cole, J. J., Prairie, Y. T., Caraco N. F., McDowell W. H., Tranvik, L. J., Striegl, R. G., ... Melack, J. (2007). Plumbing the global carbon cycle: Integrating inland waters into the terrestrial carbon budget. Ecosystems, 10(1), 172-185. https://doi.org/10.1007/s10021-006-9013-8

Dick, D. P., Novotny, E. H., Dieckow, J., \& Bayer, C. (2009). Química da matéria orgânica do solo. In V. F. Melo, \& L. R. F. Alleoni (Eds.), Química e mineralogia do solo: Parte 2-Aplicações (pp. 1-68). Viçosa, MG, Sociedade Brasileira de Ciência do Solo.

Driessen, P., Deckers, J., Spaargaren, O., \& Nachtergaele, F. (2001). Lecture notes on the major soils of the world. FAO World Soil Resources Reports 94. Rome, Food and Agriculture Organization of the United Nations. Retrieved from http://www.fao.org/3/a-y1899e.pdf

FAO (Food and Agriculture Organization of the United Nations). (1974). Soil Map of the World (Vol. 1). Paris, UNESCO.

Feitosa, K. K. A., Vale Júnior, J. F., Schaefer, C. E. G. R., Sousa, M. I. L., \& Nascimento, P. P. R. R. (2016). Relações solo-vegetação em "ilhas" florestais e savanas adjacentes, no Nordeste de Roraima. Ciência Florestal, 26(1), 135-146. https://doi.org/10.5902/1980509821098

Ferreira, E. B., Cavalcanti, P. P., \& Nogueira, D. A. (2018). Package 'ExpDes. pt'. Retrieved from https://cran.r-project.org/web/packages/ExpDes.pt/ExpDes.pt.pdf

Fonseca, J. S. (2017). Caracterização e classificação de solos em uma litossequência arenito-gnaisse em Manicoré-AM (Master's thesis, Federal University of Amazonas, Amazonas, Brazil). Retrieved from http://ppgca.ufam.edu.br/attachments/article/283/Disserta\%C3\%A7\%C3\%A3o\%20Julimar\%20Fonseca.pdf 
Furley, P. (2010). Tropical Savannas: Biomass, plant ecology, and the role of fire and soil on vegetation. Progress in Physical Geography: Earth and Environment, 34(4), 563-585. https://doi.org/10.1177/030913 3310364934

Grozav, A., \& Rogobete, G. H. (2012). Drainage of Histosols. Research Journal of Agricultural Science, 44(3), 49-54.

Guimarães, A. J. M., Araújo, G. M., \& Corrêa, G. F. (2002). Estrutura fitossociológica em área natural e antropizada de uma vereda em Uberlândia, MG. Acta Botânica Brasilica, 16(3), 317-329. https://doi.org/ 10.1590/S0102-33062002000300007

Inubushi, K., Cheng, W., Aonuma, S., Hoque, M. M., Kobayashi, K., Miura, S., ... Okada, M. (2003). Effects of free-air $\mathrm{CO}_{2}$ enrichment (FACE) on $\mathrm{CH}_{4}$ emission from a rice paddy field. Global Change Biology, 9(10), 1458-1464. https://doi.org/10.1046/j.1365-2486.2003.00665.x

Kassambara, A., \& Mundt, F. (2017). Factoextra: Extract and visualize the results of multivariate data analyses. Retrieved from https:/CRAN.R-project.org/package=factoextra

Kelly, E. F., Chadwick, O. A., \& Hilinski, T. E. (1998). The effect of plants on mineral weathering. Biogeochemistry, 42(1-2), 21-53. https://doi.org/10.1023/A:1005919306687

Kirkkala, T., Ventelä, A. M., \& Tarvainen, M. (2012). Long-term field-scale experiment on using lime filters in an agricultural catchment. Journal of Environment Quality, 41(2), 410-419. https://oi.org/10.2134/ jeq2010.0429

Lähteenoja, O., Ruokolainen, K., Schulman, L., \& Oinonen, M. (2009). Amazonian peatlands: An ignored C sink and potential source. Global Change Biology, 15(9), 2311-2320. https://doi.org/10.1111/j.1365-2486.2009. 01920.x

Lê, S., Josse, J., \& Husson, F. (2008). FactoMineR: an R package for multivariate analysis. Journal of statistical Software, 25(1), 1-18. https://doi.org/10.18637/jss.v025.i01

Ludang, Y., Jaya, A., \& Inoue, T. (2007). Geohydrological conditions of the developed peatland in Central Kalimantan. World Applied Sciences Journal, 2(3), 198-203.

Matos, F. S., Nunes, Y. R. F., Silva, M. A. P., \& Oliveira, I. S. (2014). Variação biométrica de diásporos de buriti (Mauritia flexuosa L.f.-Arecaceae) em veredas em diferentes estágios de conservação. Ciência Florestal, 24(4), 833-842. https://doi.org/10.5902/1980509816583

Meneses, M. E. N. S., Costa, M. L., \& Costa, J. A. V. (2007). Os lagos do lavrado de Boa Vista, Roraima: Fisiografia, físico-química das águas, mineralogia e química dos sedimentos. Revista Brasileira de Geociências, 37(3), 478-489. https://doi.org/10.25249/0375-7536.2007373478489

Miranda, I. S., \& Absy, M. L. (1997). Flora fanerogâmica das savanas de Roraima. In R. I. Barbosa, E. J. G. Ferreira, \& E. G. Castellõn (Eds.), Homem, Ambiente e Ecologia no Estado de Roraima (pp. 445-462). Manaus, INPA.

Morais, R. P., \& Carvalho, T. M. (2015). Aspectos dinâmicos da paisagem do Lavrado, Nordeste de Roraima. Revista de Geociências, 34(1), 55-68.

Neue, H. U., Gaunt, J. L., Wang, Z. P., Becker-Heidmann, P., \& Quijano, C. (1997). Carbon in tropical wetlands. Geoderma, 79(1-4), 163-185. https://doi.org/10.1016/S0016-7061(97)00041-4

Novais, R. F., Smyth, T. J., \& Nunes, F. N. (2007). Fósforo. In R. F. Novais, V. V. H. Alvarez, N. F. Barros, R. L. F. Fontes, R. B. Cantarutti, \& J. C. L. Neves (Eds.), Fertilidade do Solo (pp. 471-537). Viçosa, Minas Gerais, Brasil: Sociedade Brasileira de Ciência do Solo.

Page, S. E., Wüst, R. A. J., Weiss, D., Rieley, J. O., Shotyk, W., \& Limin, S. H. (2004). A record of Late Pleistocene and Holocene carbon accumulation and climate change from an equatorial peat bog (Kalimantan, Indonesia): Implications for past, present and future carbon dynamics. Journal of Quaternary Science, 19(7), 625-635. https://doi.org/10.1002/jqs.884

Pereira, M. G., Ebeling, A. G., Valladares, G. S., Anjos, L. H. C., \& Espíndula Júnior, A. (2006). Estimativa da acidez potencial pelo método do pH SMP em solos com elevado teor de matéria orgânica. Bragantia, 65(3), 487-493. https://doi.org/10.1590/S0006-87052006000300015 
Pivello, V. R., \& Coutinho, L. M. (1996). A qualitative successional model to assist in the management of Brazilian cerrados. Forest Ecology and Management, 87(1-3), 127-138. https://doi.org/10.1016/S0378-1127 (96)03829-7

R Core Team. (2017). $R$ : A language and environment for statistical computing. Vienna, Austria, R Foundation for Statistical Computing. Retrieved from http://www.R-project.org

Santos, H. G., Jacomine, P. K. T., Anjos, L. H. C., Oliveira, V. A., Lumbreras, J. F., Coelho, M. R., \& Almeida, J. A. (2013). Sistema Brasileiro de Classificação de Solos (3rd ed.). Rio de Janeiro: Embrapa Solos.

Silva, F. C. (2009). Manual de métodos de análise de solo, plantas e fertilizantes (2nd ed.). Rio de Janeiro: Centro Nacional de Pesquisa de Solos.

Soares, M. P., Reys, P., Pifano, D. S., Sá, J. L., Silva, P. O, Santos, T. M., \& Silva, F. G. (2015) Relationship between edaphic factors and vegetation in savannas of the Brazilian midwest region. Revista Brasileira de Ciência do Solo, 39(3), 821-829. https://doi.org/10.1590/01000683rbcs20130726

Sousa, R. F., Brasil, E. P. F., Figueiredo, C. C., \& Leandro, W. M. (2015). Soil organic fractions in preserved and disturbed wetlands of the Cerrado biome. Revista Brasileira de Ciência do Solo, 39(1), 222-231. https://doi.org/10.1590/01000683rbcs20150048

Sousa, R. M. G., Miranda, L. N., \& Oliveira, S. A. (2007). Acidez do Solo e sua Correção. In R. F. Novais, V. V. H. Alvarez, N. F. Barros, R. L. F. Fontes, R. B. Cantarutti, \& J. C. L. Neves (Eds.), Fertilidade do Solo (pp. 203-274). Viçosa, Minas Gerais, Brasil: Sociedade Brasileira de Ciência do Solo.

Stevenson, F. J. (1994). Humus chemistry: Genesis, composition, reactions (2nd ed.). New York: Wiley.

Vale Júnior, J. F., \& Schaefer, C. E. G. R. (2010). Gênese e geografia dos solos sob savana. In J. F. Vale Júnior, \& C. E. G. R. Schaefer (Eds.), Solos sob Savanas de Roraima: Gênese, classificação e relações ambientais (pp. 17-36). Boa Vista, Brasil: Gráfica Ioris.

Valladares, G. S., Pereira, M. G., Anjos, L. H. C., \& Ebeling, A. G. (2008). Caracterização de solos brasileiros com elevados teores de material orgânico. Magistra, 20(1), 95-104.

Vidon, P., Allan, C., Burns, D., Duval, T. P., Gurwick, N., Inamdar, S., \& Sebestyen, S. (2010). Hot spots and hot moments in riparian zones: Potential for improved water quality management. Journal of the American Water Resource Association, 46(2), 278-298. https://doi.org/10.1111/j.1752-1688.2010.00420.x

Winterdahl, M., Temnerud, J., Futter, M. N., Lögfren, S., Moldan, F., \& Bishop, K. (2011). Riparian zone influence on stream water dissolved organic carbon concentrations at the Swedish integrated monitoring sites. $A M B I O, 40(8), 920-930$. https://doi.org/10.1007/S13280-011-0199-4

Zinck, J. A. (2011). Tropical and subtropical peats: An overview. In J. A. Zinck, \& O. Huber (Eds.), Peatlands of the Western Guyana Highlands, Venezuela: Properties and Paleogeographic Significance of Peats (Ecological Studies, V. 217). New York, NY: Springer. https://doi.org/10.1007/978-3-642-20138-7

\section{Copyrights}

Copyright for this article is retained by the author(s), with first publication rights granted to the journal.

This is an open-access article distributed under the terms and conditions of the Creative Commons Attribution license (http://creativecommons.org/licenses/by/4.0/). 